position that would be more compatible with a stable family life. Had Fred's life not been cut short I am confident that this wish would have materialized.

I remember Fred as a close friend and as a man of principle who was deeply committed to a set of clearly-defined values and beliefs. I also remember him as a man of uncommon compassion and of tolerance and understanding for those who might listen to a different drummer. Fred was a conservative, I am usually considered a liberal. Fred was an active Republican, I am a lifelong Democrat. None of this ever interfered with our friendship, though it did make our relationship more interesting and lively than it otherwise might have been.

Fred was immensely proud of his family and of their accomplishments. He always proudly displayed many family pictures and mementos in his office at the university. Pixie taught at a nearby Lutheran school and Fred was sure that she had a natural talent for handling young children that no one could top. Although his own commitments were heavy, because his teaching schedule was more flexible than hers, Fred often assumed responsibility for getting Michelle and Melanie off to school, responding to their calls of distress in the event of illness or other emergencies, and did some of the household chores. I never knew Fred to treat any of these duties as a burden. Rather, he always accepted them as opportunities which it was his special privilege to perform.

Fred will be missed by all who knew him, but he would not have us linger long mourning him. Fred's counsel would be to get on with life. Our only obligation, for those of us whose lives he touched, is to remember Fred's example and to do what we can to make the world a better place.

J. D. Phaup

Texas A\&I University

\section{William C. Velasquez}

William "Willie" Velasquez passed away quietly at 12:57 a.m., June 15, 1988. Willie had been diagnosed as terminally suffering from kidney cancer which spread rapidly to his lymph nodes and other vital organs. Many who knew Willie were shocked and saddened by the swiftness of his passing.

Although not technically a political scientist, Willie was an astute student of our discipline-he graduated with advanced degrees in community organizing courtesy of his stints in the late 1960s with the United Farm Workers Union and during the early 1970s with El Partido de La Raza Unida. Mr. Velasquez was not merely a keen political observer but one of the most versatile, intellectual and persistent practitioners of political science that the Civil Rights Movement has witnessed. He founded the Southwest Voter Education Project in 1974 and by July of 1988 he would have completed organizing his 1,000 non-partisan voter registration campaign throughout the Southwestern United States. In 1984 he founded the Southwest Voter Research Institute to conduct survey and policy research of, and for, the Hispanic community.

Many compared Willie's importance to the voting and civil rights of Hispanics to that of Martin Luther King's importance to the black community. Equally as important Willie was a friend and advisor to many, including those who aspired to the Presidency and to working class people wishing to participate more fully in the electoral process. Of foremost and singular importance, however, Willie was a devoted husband and father; he had planned to write a book on the socio-political evolution of Latinos in the Southwest which he hoped would pay for his children's Harvard education.

Those of us who were close to Willie and shared his concerns for social justice have been deeply bereaved by his sudden departure. However, his vision of obtaining full political equality for Hispanics will not be lost or forgotten by those he left behind. If he had made a last wish, we feel that Willie would have wanted that we continue the work he had started.

We will miss his ascerbic humor-when told of his cancer he told everyone how relieved he was in that he thought he was merely "burned out" - his almost spiritual 
presence, and his undying loyalty to his family, people, and La Causa.

Robert Brischetto

Southwest Voter Research Institute

Charles L. Cotrell

Bro. Thomas Hoffman, S.M.

Henry Flores

Department of Political Science

St. Mary's University

\section{John Albert Vieg}

John A. Vieg, Emeritus Professor of Government at Pomona College, died at home in Claremont, California, on February 12, 1988. Though he was in his eightythird year, the day before his death was spent in a manner typical of his life-long involvement in the world about him. He attended a meeting at Pomona College on the liberal arts curriculum, and at lunch participated in a spirited discussion of the presidential primaries, offering as always various proposals for the reform of the political system. That night he attended a community committee meeting.

A student of Charles Merriam at the University of Chicago in the 1930s, John Vieg managed to combine a strong sense of the empirical rigor and systematization necessary for a genuine discipline of polit$i c a l$ science with a continuing reformist zeal and irrepressible optimism, Not just the good cheer which he had in abundance, but a dedication to a cause lay behind his efforts as a founding father of the Western Political Science Association, which he served as President in 1959-60, or the Southern California Political Science Association, which he was instrumental in founding. He was on the Council of the American Political Science Association in 1947-50, and Vice President of the Association in 1958-59.

Born in Fort Dodge, lowa, Vieg earned an A.B. degree in history from St. Olaf College in 1926. He was Phi Beta Kappa and class president. He continued in his- tory for his master's degree at the University of lowa, and taught history at Burlington Junior College until he headed for the University of Chicago in 1934. For his Ph.D. he switched to political science, the better, he said, "to change the world." Those who knew John realize that such a remark, which can be taken two ways, has to be taken two ways: both as wry selfdeprecation and as an expression of powerful ambition. His doctoral dissertation, on the politics of the Chicago city schools, was later published as a book. A student of public administration, American political parties, and municipal government, his interests expanded to state, national, and international levels. His focus was what today would be called public policy. He had a bemused suspicion of empty philosophical abstractions and liked to bring problems down to a practical level, where alternative solutions for improvement of whatever was being studied could be compared. He began teaching political science at lowa State and quickly found himself Vice-Chairman of the Ames Planning Commission and an officer in what was then the Midwest Conference of Political Scientists.

During World War II he went to Washington as an analyst for the Bureau of the Budget, on loan for a time to the LendLease Administration. After the war he came to Pomona College and served as Chair of the Department of Government until his retirement in 1970. At Pomona he taught almost everything in the curriculum at one time or another, and presided over the gradual expansion of the department from a staff of three to six and beyond. $\mathrm{He}$ was on innumerable committees and, at one critical time in the fifties, served as Chair of the Coordinating Committee in Economics and Government at the Claremont Graduate School. His colleagues uniformly remark on his warm support and encouragement, his helpfulness in many small but important ways, his generosity, and his playful, never caustic, sense of humor, somewhat paradoxically combined with a courtly, dignified manner. He exuded a genuine interest in what students wanted to do and wanted to be. He could chide them gently when they took them. selves too seriously. He paid very close 